\title{
DESTINATION MARKETING THROUGH FILM TOURISM: A STUDY ON WESTERN ORISSA
}

\section{Shwetasaibal Samanta Sahoo, * Sarat Kumar Lenka**}

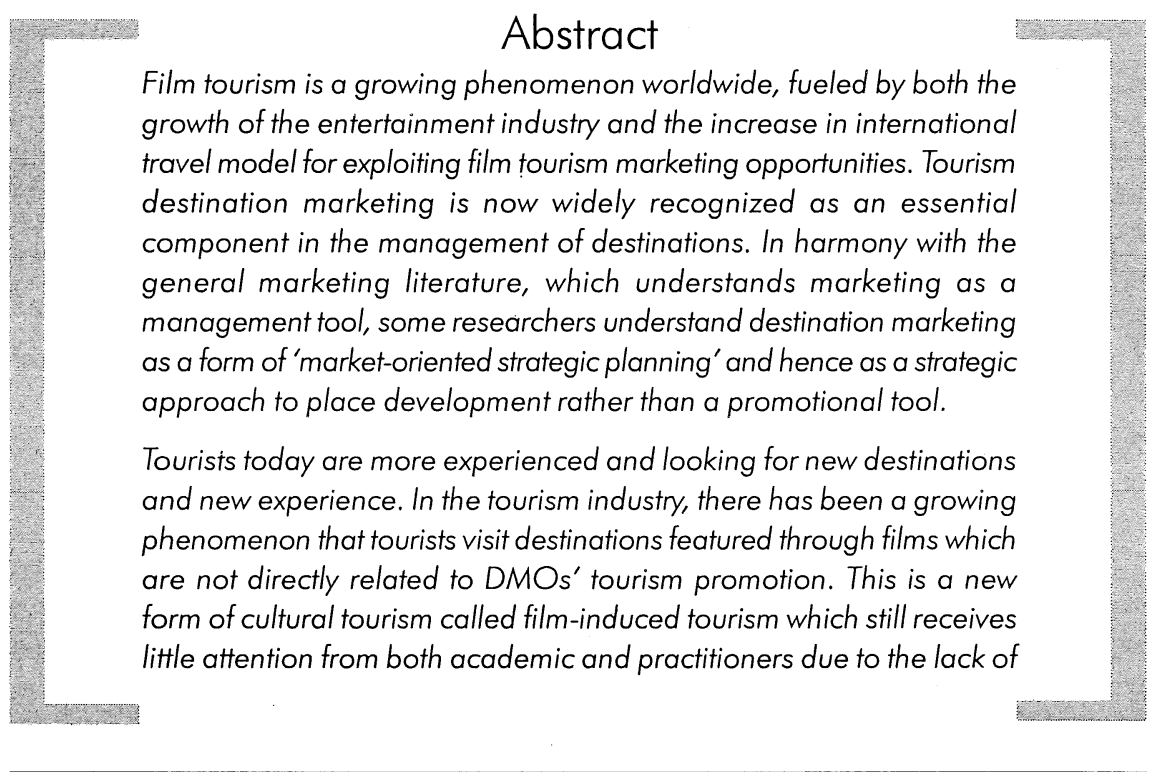

* Research Scholar, Utkal University, Orissa.

** IITTM, Bhubaneswar. 
knowledge and understanding on the benefits of film on tourism. Recent research suggests that films can have strong influence on tourist decisionmaking and films do not only provide short-term tourism revenue but long-term prosperity to the destination. The primary focus of this article is to provide a theoretical insight into the relationship between films induced tourism and destination imagery, which in turn can be used to market Western Orissa.

\section{Introduction}

Tourism today is a growing concept and covers a broad range of activities. We cannot refer anymore to tourism simply as the business of going on holiday. We need to understand deeply all the range of leisure-time activities covered in it and what the main motivational factors are?

The tourism industry has reached the stage of maturity. Tourists today are more experienced and become selective in their choice of holidays, in terms of destination and activities. The tourism industry itself is very competitive with many new destinations trying to attract the tourists to their destinations. The days that Destination Marketing Organizations (DMOs) just simply promote the destinations and then wait for the tourists to visit the destinations are gone. Today tourists need to be enticed in which destinations have to be marketed effectively to maintain the market share and attract new market segment (Ashworth \& Goodall, 1990). DMOs have to shift the conventional concept of 'selling existing places' to 'inventing new destinations to be sold'. The emphasis should therefore be on destination positioning and differentiation.

There have been an increasing number of tourists visiting destinations featured through films and television series which are not directly related to tourism promotion campaigns. This phenomenon is called film-induced tourism or movie-induced tourism. Film-induced tourism is defined as tourist visits to the destination featured on television, video, or cinema screen (Hudson \& Ritchie, 2006).

Falling loosely under the umbrella of cultural tourism, film tourism is a growing phenomenon worldwide, fueled by both the growth of the entertainment industry and the increase in international travel. The benefits of film tourism are becoming increasingly apparent. Appealing to wide and diverse markets, film tourism offers something for everyone, just like the films themselves, and tourism organizations can use films as springboards for marketing campaigns if the films are seen as appropriate for the destination. Marketing opportunities are generated when the 
film is being premiered and distributed as well as during each release window. Additional businesses and services can be created through film tourism that in turn can encourage the extension and strengthening of the visitor season.

Different forms and characteristics of film tourism can be summarized as follows:

\begin{tabular}{|c|c|}
\hline Form & Characteristics \\
\hline $\begin{array}{l}\text { 1. Film-induced tourism as } \\
\text { part of a main holiday. }\end{array}$ & $\begin{array}{l}\text { Tourists will visit film location or book } \\
\text { a film tour for a holiday without any } \\
\text { previous destination knowledge. }\end{array}$ \\
\hline $\begin{array}{l}\text { 2. Film-induced tourism as } \\
\text { a main purpose out of } \\
\text { special interest. }\end{array}$ & $\begin{array}{l}\text { The booking of a holiday to a } \\
\text { destination as a result of its } \\
\text { profiles on the screen. }\end{array}$ \\
\hline $\begin{array}{l}\text { 3. Film-induced tourism icons } \\
\text { as focal points of visit. }\end{array}$ & $\begin{array}{l}\text { Natural beauty, historical places, } \\
\text { actors can serve as icons. }\end{array}$ \\
\hline $\begin{array}{l}\text { 4. Film-induced tourism to } \\
\text { places where filming is } \\
\text { only believed to have } \\
\text { taken place. }\end{array}$ & $\begin{array}{l}\text { Tourists visit the filming places } \\
\text { even if the film represents a } \\
\text { different setting. }\end{array}$ \\
\hline $\begin{array}{l}\text { 5. Film-induced tourism as } \\
\text { part of romantic gaze. }\end{array}$ & $\begin{array}{l}\text { ourists like to gaze on places } \\
\text { Treinforced by the films in } \\
\text { solitude, establishing a } \\
\text { semi-spiritual relationship with } \\
\text { the place. }\end{array}$ \\
\hline $\begin{array}{l}\text { 6. Film-induced tourism for } \\
\text { reasons of escape. }\end{array}$ & $\begin{array}{l}\text { Visiting film locations elevates } \\
\text { tourists beyond the mundane } \\
\text { reality of everyday life. }\end{array}$ \\
\hline
\end{tabular}

\section{Benefits of film Tourism}

- One of the major economic benefits that film induced tourism can bring to the local community is enduring tourism receipts. Film locations can be all-year, all-weather attractions which alleviates problems of seasonality in the tourism industry. 
- Another significant benefit of the film tourism is that it increases the cultural value for the film location. Film tourism is a medium of which a range of cultural meanings and values may be communicated. Many heritage sites that serve as film locations gain popularity after the film release because these places acquire specific meaning through film narration.

- Film can enhance the destination image and increase the awareness about the host city. Television series are even more powerful since they can continuously reinforce the appeal of the destination which builds top-of the mind awareness.

\section{Literature Review}

It has been widely recognized in tourism literature that destination image greatly influences tourist destination choice. Images of destinations play a significant role in influencing tourist decision-making process as the basis for tourists to make choice about where to visit (Gartner 1989; Echtner \& Ritchie 1991). The more favourable the image of the destination, the greater the likelihood of being selected as a destination choice (Chon 1990; Um 1993). Butler (1990) suggests that films can influence the travel preference of those who expose to the destination attributes and create a favorable destination image through their representation. Film can provide knowledge of certain aspects of the country such as nature, culture and people which result in the construction of the attitudes towards the country. An interest in the nation and its positive image can eventually lead to an actual visit to the country (Iwashita, 2006).

Leisure activities such as watching films as well as traveling are ways to escape. Both provide temporary relief from the real world (Carl et al., 2007). Films can induce viewers to travel by the physical properties (scenery and landscape) and their associated theme, storylines, events and actors, shaping the audience' feelings, emotion and attitudes towards places. Location and film experiences are enhanced in memories by associating them with the actors, events and setting (Iwashita 2006; Riley \& Van Doren, 1992). The world of associations and sentiments are enclosed in the viewers' minds as memories and obsessions which give meaning to the locations. Locations, events and characters become iconic attractions as a result of being given powerful meanings in film narrations. People tend to visit particular places by specific images, memories, associations and emotional attachments to places and meanings (Schama, 1996).

According to Morgan and Pritchard (1998), placing a destination in a film is the ultimate in tourism product placement. Product placement is an emerging phenomenon, and has been defined as the planned entries of products into movies 
or television shows that may influence viewers' product beliefs and/or behaviors favorably (Balasubramanian 1994). Its growth has been spurred by the diminishing effectiveness of traditional advertising techniques (Kaikati and Kaikati 2004), and marketers are realizing that communications via product placement can be more sophisticated, more targeted, and more widely seen than traditional advertising methods (Karrh, McKee, and Pardun 2003).

Recently, branding has been used by destination marketers who believe that the concept is as applicable to destinations as it is to airlines, attractions, hotels and restaurants (Seaton and Bennett 1996: 130). Many tourism researchers (Chambers 1989; Nasser 2003) consider that tourism destinations can improve their success levels by forming a resilient brand strategy which enhances their market share as seen Glasgow's Miles Better (1977) campaigns, irrespective of where destinations are in the life cycle.

\section{Methodology}

Films are acting as 'virtual holiday brochures', having a significant impact on how tourists choose their holiday destinations. Some studies show that majority of tourists plan their holidays after seeing a location on the big screen.

Tourism and Film are both huge industries. They are facing a constant process of innovation to attract the attention of the modern mass consumer overwhelmed by a growing number of products, service media advertise and promotion.

Despite the potential of the links between film and tourism are growing faster, thanks to cases as The Lord of The Rings, relatively little has been written about their intersection until recent years. This lack of specific studies can be attributed to the difficulties faced by researchers in isolating film's impact on tourism from a large variety of stimulus as other media, marketing activities, events and social behaviour. The topic of Film Tourism (also referred to film-induced tourism or movie induced tourism) is complex, embracing in itself many issue and for this reason can be approached from different perspectives as psychology, sociology, marketing and management.

The research on the concerned topic examines the impact of film induced tourism and destination branding on locations featured in popular films and television series. It also investigates the characteristics and benefits of film induced tourism. Western Orissa was selected as the case study area, as it has tremendous tourism potentials to be popularized through film and television series. 
The study also intends to find out the marketing \&other suitable strategies how destination managers, maximizing the links between film and tourism can boost the two industries and bring in this way several benefits on the economic development of a destination in Western Orissa. The researcher mainly had to depend upon the secondary data for carrying out the research.

\section{Orissa tourism- An overview}

Orissa is a state of Indian union located along the eastern coast of peninsula. It is bounded by Bay of Bengal in the East, West Bengal in the northeast, Jharkhand in North, Chattisgarh in West and Andhra Pradesh in South. its territory formed a part of ancient kingdom of Kalinga of Mahabharata fame situated along the cost of bay of Bengal Orissa stands for its ancient glory and modern endeavour endowed with nature's boundary a $482 \mathrm{Km}$ stretch of coast line with virgin beaches, serpentine rivers, mightily waterfalls, forest-clad, blue hills of eastern ghats with wild life, Orissa is dotted with exquisite temples, historic monuments as well as pieces of modern engineering feat. The land, while retaining its pristine glory also offers the visitors modern amenities. Its lush green country side and mangroves offer a charm of rural beauty while the urban pockets, with splendour of modern technology provide the amenities necessary for a comfortable stay.

Orissa has been a preferred destination from ancient days for people having interest in spirituality, religion, culture, art and beauty of the nature. Ancient and medieval architecture, pristine sea beaches, nature at her beautiful best, the classical and ethnic dance forms and a variety of festivals, all in combine attract tourists from far off places to explore this state to a have a divine exposure of love and hospitality.

The recent efforts in putting the state in the national and global map of tourist attractions are all set to pay rich dividends. With the punch line of "Scenic, Serene and Sublime, the government is targeting to cash on the rich cultural heritage of the state. Orissa is not only a tourist site at the same time it is also a researcher's delight. Orissa boasts of people having innocent, uncorrupt and unadulterated love towards the visitors and at the same time provides modern facilities for transport and communication. This is a rare combination of innocence and modernity.

Tourism has been recognized as an industry in Orissa and sizeable revenue is earned for the State from domestic as well as foreign tourists. The idea of tourism was first mooted by the Government during the 3rd Five Year Plan. It was revamped during the 5th Five Year Plan. The creation of Department of Tourism, Govt. of 
Orissa dates back to 1973. There have been modifications from time to time as regards the sphere of function of the Department. The Department of Tourism and Culture has been functioning in the present shape since 1995. The Orissa Tourism Development Corporation was created in March 1979 and it was incorporated under Companies Act in September 1979.

Form both the sides, Government as well as Corporation, thrust was given on the modernization of the sightseeing spots of Orissa. The spots are generally Konark, Puri, Nandankanan, Chandipur and other tourist spots having a close proximity with the capital city. At the initial stage, with a meager budget, the Department could not cope with the pressing demands of tourists. Later, the Government decided to streamline and spread its activities not only to coastal districts but also to Western Orissa where tourist spots are also attractive.

\section{Tourism in Western Orissa}

Places of natural beauty are in abundance in Western Orissa. The natural stream and forest resources at Harisankar in Bolangir move the heart of the tourists. Equally Nrusinghanath presents a panoramic view. The deity of Nrusinghanath sitting in the shape of a half-human and half-lion form tearing apart Hiranyakasipu against the backdrop of a stream is a scene to witness. Of course, now a days, both the Department and Corporation have swung into action to create infrastructural facilities for the tourists. Apart from those two natural spots, Kalahandi district is endowed with the wealth of forests with rare species of black tigers, a natural water fall at Rabandar and a host of temples situated at the peak of mountain hills at Bhawanipatna. These are also places of tourist's importance. The Patala Ganga spot at Nuapara District is also a place of attraction for tourists. Ushakothi, Hirakud and Budrama in Sambalpur district attract the attention of tourists. Similarly, the Khandadhar Waterfall in Sundargarh district is also a tourist spot. The Mahanadi and the Tel River in Suvarnapur district present beautiful natural scenes and the confluence of the two rivers present a memorable sight.

In spite of the above tourism potentials, the Western part of Orissa is highly neglected and not been very popular among the domestic and foreign tourists. Due importance has not been given to Western Orissa in advertising and publicity activities by the Government. 


\section{What can be promoted through film tourism?}

\begin{tabular}{|c|c|}
\hline Districts & Tourist Destination \\
\hline Sundargarh & $\begin{array}{l}\text { Sundargarh, Rourkela, Junagarh, Vedavyas, } \\
\text { Uhsakothi, Mandira, Khandadhara, Deodaraha, } \\
\text { Ghogar, Darieeng, Miriglotah and Chhatri Hill }\end{array}$ \\
\hline Sambalpur & $\begin{array}{l}\text { Sambalpur, Hirakud, Huma, Chiplima, Ushakothi \& } \\
\text { Gudguda }\end{array}$ \\
\hline Jharsuguda & Jharsuguda, Viramkhol, Brajarajnagar \\
\hline Bolangir & $\begin{array}{l}\text { Bolangir, Harishankar, Patnagarh,Ranipur, Jharial, } \\
\text { Jogisarada, Turkela and Saintala }\end{array}$ \\
\hline Bargarh & Bargarh and Nursinghanath \\
\hline Deogarh & Pradhanpat (on the outskirt of Deogarh Town) \\
\hline Kalahandi & $\begin{array}{l}\text { Bhawanipatna, Ampani, Phurli -iharan, Karlapat, } \\
\text { Asurgarh, Belkhandi,Gudahandi, Junagarh and } \\
\text { Thuamul Rampur }\end{array}$ \\
\hline Nuapada & Nuapada, Budhikomna, Yogimatha, and Patalganga \\
\hline Sonepur & Sonepur, Charada of Binka (Papaks-hayaghat) \\
\hline
\end{tabular}

\section{Film Tourism Destination Marketing Strategy- Western Orissa}

\section{Destination image}

Destination image has always been important to tourism boards, and films offer them not only a big screen to showcase beautiful landscapes, but also the ability, with branded entertainment strategies, to develop more sophisticated strategies that are meant to protect and increase the integrity of their brand. Bolan and Williams (2008) state that image formation for consumers are a combination of information gathered through various mediums agreeing with Reynolds (1965), 
that just a few impressions are more heavily weighted than others to form an individual's ultimate attitude. This suggests that stimuli which create large emotional impact have a great influence over consumer perception.

Film and other electronic content seem to have an advantage for creating impact as the use of motion, sound, and visuals that affect emotion are key elements within these mediums and have also proven to be the basis of dynamic creative executions (Belch \& Belch, 2009). However, mediums that do not have these inherent, emotional elements can also attempt to maximize message impact through repetition strategies.

Image is not purely created through media vehicles. Image perception is a combination of all an individual's experiences with a product or brand. A destination's image is affected by word-of-mouth and actual visits to the destination in addition to a myriad amount of information gathering. Gunn (1972) suggested a dichotomy whereas organic images (nonbiased news, etc.) are affected by induced images that are strategically distributed through such mediums as film and television. Together, the body of information is used for individuals to develop perception and attitudes toward messages that affect their decision-making process whether or not to visit a destination. Organic information is more difficult than induced information for destination marketing organizations to control, yet destination information does get distributed through organic channels. A strategy that feeds organic channels consistently with destination information that is on message with the overall tourism strategy can complement a more calculated branded strategy.

Rather than utilizing individual techniques to develop a brand image for destinations of Western Orissa, it is essential that a destination marketing organization coordinate and integrate all its efforts to maximize impact to create a consistent and relevant image (Gallarza, Gil Saura \& Calderon Garcia, 2002). This approach not only affects how an organization develops its identity through communications techniques, but it can also affect how the infrastructure of the destination is shaped. A vision must be communicated that considers both destination infrastructure and brand strategy. Some elements of such synergy will be realistic or controllable while other elements will be harder to execute. However, a proper assessment and planning process is necessary for a coordinated and integrated brand effort for Western Orissa.

\section{Branded content and destinations}

The first stage of brand development is to assess the uniqueness of the destination brand, a process that acts as an internal audit of the brand's value. Different 
advertising agencies use variations of the same method, but essentially, the brand is assessed against other brands in different categories to get a sense of what similar characteristics other brands in different product categories have as the base brand being measured. The relationship to other categories is meant to identify the types of products or brands that fit within the target markets' lifestyles. It is a process to stretch the creative thinking process and develop a holistic view of the consumer and the brand characteristics that are relevant to the market. Typically three to five characteristics are identified that uniquely describe the brand, sometimes referred to as vivid descriptors, and these characteristics are used as a basis for the creative brand strategy. Often, the group of characteristics is boiled down to one word that drives the creative strategy. Fundamentally, these characteristics become the underlying association of the brand image sought. It is important to mention this creative method here because any strategic film tourism or branded entertainment strategy should be concerned with the final outcome ensuring that the outcome reflects the core characteristics and associations of the brand.

Film tourism strategies should not attract production companies to destinations of Western Orissa solely to ensure landscape placement. Destinations of Western Orissa need a more sophisticated attempt toward complementing overall tourism strategies. Destination marketing organizations should consider shifting their efforts, and focus on the conceptual stage rather than the production stage of content development. This new shift in focus should be coordinated with a more strategic effort in discovering the destination's core brand characteristics. The compatibility between the destination's brand characteristics and content of potential scripts will give film tourism a new focus that begins to look more like a branded entertainment strategy for destinations than simply providing relevant backgrounds for scripts. Brands strive to become part of the vernacular of society, what better strategy then to imbed the beauty and services available at destinations throughout a film or television series that has real meaning to the messages communicated in the plots. Kim and Richardson (2003) suggest that film and television affect societal beliefs, and that movies are part of popular culture and offer opportunities for brand exposure that are unobtrusive. Opportunities exist for strategic and subtle visibility to mass audiences for destinations through various types of production, and this visibility offers a platform to present the emotive side of the destination's brand in more sophisticated ways.

Like the other destinations, the success of film tourism in western Orissa will depend on five factors: destination marketing activities, destination attributes, film-specific factors, film commission and government efforts, and location feasibility. Despite suggestions that destination marketers have neglected this very effective form of publicity (Cohen 1986), a review of the secondary research related to film tourism 
suggests that some destinations have leveraged the visibility that films provide and benefited by showing a significant rise in visitor numbers following a film's release.

The following model suggests that destination marketing organizations (DMOs) can engage in a variety of marketing activities both before and after release of a film, and these are described below.

Film Tourism Marketing strategies

Film Tourism

Marketing Activities

\begin{tabular}{|c|c|}
\hline Before Release & lease \\
\hline $\begin{array}{l}\text { - Appoint an executive or public } \\
\text { relations. specialist to deal with film } \\
\text { studios directly } \\
\text { - Actively promote the destinations } \\
\text { of western Orissa to film studios. } \\
\text { - Offer grants and tax credits to } \\
\text { encourage Studios to use the } \\
\text { location of Western Orissa. } \\
\text { - Be actively involved in location } \\
\text { scouting. } \\
\text { - Plan carefully to maximize the } \\
\text { impacts of postproduction } \\
\text { exposure. } \\
\text { - Carefully assess a film's merit in } \\
\text { terms of its promotional value. } \\
\text { - Negotiating and/or produce a } \\
\text { 'making of the Film' feature. } \\
\text { - Engage the film's stars to promote } \\
\text { the film Location of Western Orissa. } \\
\text { - Provide images of destinations for } \\
\text { media or tour operators to use in } \\
\text { promotions through CDs, Websites, } \\
\text { brochures, Pamphlets etc. }\end{array}$ & $\begin{array}{l}\text { - Invite travel media to special } \\
\text { release of the film. } \\
\text { - Post signage and interpretation } \\
\text { of the location. } \\
\text { - Sell film memorabilia. } \\
\text { - Replicate or maintain film icons/ } \\
\text { sites/scenes/sets to maintain } \\
\text { authenticity. } \\
\text { - Host events that continue the pull } \\
\text { of the film beyond its natural } \\
\text { audience peak. } \\
\text { - Develop a dedicate website for } \\
\text { potential tourists for western } \\
\text { Orissa. } \\
\text { - Post links on website to film tours } \\
\text { run by local tour operators. } \\
\text { - Engage in joint promotional } \\
\text { activity with inbound tour } \\
\text { operators. } \\
\text { - Package additional attractions to } \\
\text { lengthen tourist stay in western } \\
\text { Orissa. } \\
\text { - Work collectively with other } \\
\text { authorities to promote film } \\
\text { locations of Western Orissa }\end{array}$ \\
\hline
\end{tabular}




\begin{tabular}{|c|c|}
\hline Before Release & After Release \\
\hline $\begin{array}{l}\text { - Ensure media coverage of the film } \\
\text { mentioning the film location. } \\
\text { - Invite travel media such as TV, } \\
\text { travel magazines etc to film } \\
\text { location of Western Orissa. } \\
\text { - Sponsor the film directly. } \\
\text { - Plan activities to promote other } \\
\text { tourism sectors such as art \& } \\
\text { crafts, fairs and festivals, music } \\
\text { and dance, cuisine etc. }\end{array}$ & $\begin{array}{l}\text { - Engage in joint promotional } \\
\text { activity with film companies. } \\
\text { - Create electronic links to the } \\
\text { - Havtination on the film website. } \\
\text { walks. } \\
\text { - Produce film and site maps for } \\
\text { - } \text { Courists } \\
\text { - } \text { meate exhibitions or displays of } \\
\text { attract continuours and/or film } \\
\text { release window the location at each }\end{array}$ \\
\hline
\end{tabular}

\section{Marketing activities before release}

Despite the fact that DMOs often cannot be selective of films being produced, they can be proactive in promoting their locations to film producers. Most destinations have a short-term focus that facilitates film production, concentrating on the associated economic impacts (Croy and Walker 2003), but some are becoming active in encouraging producers to make films in their region to benefit from the long-term tourism impacts. DMOs in Britain, Kansas, and Singapore are examples. Visit Britain has been targeting Indian film producers for some time in the belief that they can be persuaded to use British locations for Bollywood films and thereby generate significant economic benefits for Britain's tourism industry (Woodward 2000).

\section{Marketing activities after release}

During and after release of a film, media attention can be attracted to the film location of Western Orissa. The Tourism Authority of Thailand (TAT), for example, heavily advertised its attractions during release of the film The Beach (Grihault 2003). Promoting the destination during the screening of a film is another way to attract attention to a destination. The Scottish Tourist Board distributed direct-response postcard adverts in cinemas that were screening Braveheart, inviting viewers to send for information on Braveheart Country (Grihault 2003). 


\section{Conclusion and recommendations}

The tourism industry is a tremendously competitive market place in which stakeholders are faced with the job of developing successful techniques to reach their target markets. The conventional tourism marketing media such as television promotion and literature have become dull and even though these media tend to be widespread, their success appears to be minimal compared to that of films. Tourists are visiting a destination after having seen the location in a film or television series is an emerging phenomenon; and due to the perceived benefits, many films have had tourism stakeholders in their locations explore the issues relating to film induced tourism (Safari Kinkead 2002). Film induced tourism is partially based on tourist demands to escape reality, to the better world represented in films. By understanding the film tourist phenomenon, tourism and film stakeholders can better meet experiences, thus expanding on the positive impacts in such destinations (Carl et al. 2007: 60)

Film tourism planning has not received much attention in Orissa while it is been treated as the new market opportunity for many (new or existing) destinations. Film and television series are strong tourism inducers and image-makers and it would be beneficial for Western Orissa to incorporate filming into destination marketing plans. Once Western Orissa becomes aware of the nature of film-induced tourism, it will feasible to integrate suitable marketing and demarketing strategies into the destinations marketing plans which will assist in creating a sustainable tourism product (Beeton, 2005: 5). The internet and indeed television offers great opportunities for creating a strong destination brand. There are numerous advantages associated with these interactive marketing tools over the traditional branding methods used to brand mainly the reduction in costs and lead times. Conversely, Palmer (2004) states that having a website in itself is not enough to promise continuous success of a tourist destination. In an age when each destination can create an interactive marketing tool, a website must be able to develop its market position and promote a strong electronic presence. Never before have DMOs' had so many routes to reach their target markets and these should be maximized upon (Palmer, 2004: 139). Tourism Australia developed a marketing campaign for the recent film Australia (2008). They financed the film director Baz. Tourism Australia is the Government Statutory Authority who is responsible for promoting Australia to the international market. Orissa Government also should finance for the movies to promote Western Orissa through film tourism.

The development of film induced tourism was reviewed and analyzed to provide an overview of implementation of various measures in branding and promotion of Western Orissa. It has been shown that film induced tourism has the potential to 
offer many opportunities but also has many potential risks. However the destination planners must be aware \& take preventive measures while planning for promotion of Western Orissa through film tourism for its sustainability. It should be not only be the responsibility of the Government, involvement of private sector and the local community can play a significant role for the successful implementation of film induced tourism in Western Orissa.

\section{References:}

Ashworth, G. J. \&\&\& Goodall, Brian (1990), Marketing Tourism Places, Routledge (London and New York).

Barton, R. (2000) The Ballykissangelization of Ireland, Historical Journal of Film, Radio and Television, 20(3), pp. 413-426.

Beeton, S. (2001) Smiling for the camera: the influence of film audiences on a budget tourism destination, Tourism Culture and Communication, 3(1), pp. 15-25.

Beeton, S. (2004) Rural tourism in Australia-has the gaze altered? Tracking rural images through film and tourism promotion, International Journal of Tourism Research, 6(3), pp. 125-135.

Beeton, S. (2005) Film-Induced Tourism (Clevedon: Channel View Publications)

Butts, F.B. (1992) The impacts of on-location filming of a motion picture on tourists' level of enjoyment while attending a major coastal attraction, Journal of Hospitality and Leisure Marketing, 1(3), pp. 31-39.

Bolan, P. \& Williams, L. (2008). The role of image in service promotion: focusing on the influence of film on consumer choice within tourism. International Journal of Consumer Studies, Vol. 32, No.4, pp.382-390.

Carl, D., Kindon, S. and Smith, K. (2007) Tourists' experiences of film locations: New Zealand as "Middle-Earth", Tourism Geographies, 9(1), pp. 49-63.

Chan, B. (2007) Film-induced tourism in Asia: a case study of Korean TV drama and female viewers' motivation to visit Korea, Tourism, Culture and Communication, 7(3), pp. 207-224.

Chon, K. S. (1990) the role of destination image in tourism: a review and discussion. The Tourist Re-view, 45(2), 2-9.

Croy, W.G. \& Walker, R.D. (2003). Rural tourism and film: Issues for strategic regional development. In D. Hall, L. Roberts and M. Mitchell (Eds.), New Directions in Rural Tourism, UK: Ashgate Publishing Ltd.

Hudson, S. and Ritchie, B. (2006b) Film tourism and destination marketing: the case of Captain Corelli's Mandolin, Journal of Vacation Marketing, 12(3), pp. 256-268.

Iwashita(2006), Role of film and Television drama in International Tourism, Polytechnic University, Hong Kong, 166-181

Kaikati and Kaikati 2004, How to Reach Consumers Surreptitiously, California Management Review. 
Kim, H. \& Richardson, S.L. (2003). Motion picture impacts on destination images. Annals of Tourism Research, Vol. 30, No.1, pp.21.6-237.

Karrh, J.A., Brittain McKee, K. \& Pardun, C. (2003). Practitioners' evolving views on product placement effectiveness. Journal of Advertising Research, Vol. 43, No.2, pp.138-149.

Reynolds, W.H. (1965). The role of the consumer in image building. California Management Review, Vol. Spring, pp.69-76.

Ritchie, B. (1984) Assessing the impact of hallmark events: conceptual and research issues, Journal of Travel Research, 23(1), pp. 2-11.

Sargent, A. (1998) The Darcy effect: regional tourism and costume drama, International Journal of Heritage Studies, 4(3), pp. 177-186.

Tourism in Western Orissa, (2002). Dept. of Tourism and Culture, Bhubaneswar. Govt. of Orissa.

Tourism in Orissa, (2002). Dept. of Tourism and Culture, Bhubaneswar. 